\title{
POWERING NIGERIA THROUGH RENEWABLE ELECTRICITY INVESTMENTS: LEGAL FRAMEWORK FOR PROGRESSIVE REALIZATION
}

\author{
Peter Kayode Oniemola*
}

\begin{abstract}
$\mathbf{R}$ enewable energy has a prominent role in promoting energy access Kand addressing environmental concerns with energy use in Nigeria. However, there are legal barriers that have not allowed renewable energy to be used in the Nigerian electricity sector. The absence of an effective legal framework to encourage and promote investment in renewable energy is a major challenge. This article investigates the barriers to promotion of investment in renewable electricity in the country. These barriers include the lack of unison and clarity of roles for institutions relevant to the promotion of renewables, high cost and lack of funds, inability of consumers to bear the cost of subsidies, lack of priority access and connection to the grid, short licensing duration, and lack of adequate and reliable information, which consumers, investors and the government can rely upon. To address these concerns, and to make investments in the renewable energy sector more favourable, there is the need to develop an effective legal framework that addresses barriers to investment in renewable electricity. This article presents insights on how the law can be used as an instrument for realizing the development of renewable electricity in Nigeria.
\end{abstract}

Keywords: Renewable, energy, power, electricity, investment, sustainable development.

doi: http://dx.doi.org/10.4314/jsdlp.v6i1.4

* LL.B (Ilorin), BL (Nigerian Law School), LL.M (Ibadan), PhD (Aberdeen), Legal Practitioner \& Consultant email: petermola@yahoo.com. 


\section{INTRODUCTION}

R enewable energy sources such as biomass, geothermal, hydropower, Rsolar and wind, energy sources are by their nature infinite and environmentally friendly when compared to conventional energy sources such as coal, oil and natural gas. ${ }^{1}$ There is, therefore, a global shift to support the promotion of renewable energy. ${ }^{2}$ Investment in renewable electricity would be desirable for increasing energy security, mitigating climate change and promoting economic development. ${ }^{3}$ However, the electricity sector is dominated by oil and gas consumption. ${ }^{4}$ Most investment in the sector is currently in oil and gas generating plants. ${ }^{5}$ Owing to prolonged investment and economies of scale, the cost of generation of electricity from oil and gas is lower than that of renewable energy installations. ${ }^{6}$ Apart from hydropower, renewable energy sources hardly feature as part of Nigeria's energy mix.

The energy crisis in Nigeria is characterized by lack of energy access and unsustainable utilization of the country's abundant energy sources. ${ }^{7}$ Therefore, only 40 per cent of the population have access to basic energy services. ${ }^{8}$ To address Nigeria's energy crises, the power sector reform is

1 See O.O. Ajayi and O.O. Ajayi, "Nigeria’s Energy Policy: Inferences, Analysis and Legal Ethics toward RE Development" (2013) 60 Energy Policy 61, 61-62. See also D. Olawuyi, "Power Generation through Renewable Energy Sources: An Analysis of the Legal Barriers and Potentials in Nigeria” (2013) 10 (2) Journal of Resources, Energy and Development.

2 S.C. Bhattacharyya, "Renewable Energies and the Poor: Niche or Nexus?" (2006) 34 Energy Policy 659, 659.

3 H. Bjørnebye, Investing in EU Energy Security: Exploring the Regulatory Approach to Tomorrow's Electricity Production (Kluwer Law International 2010) 390.

4 S. Amadi, "The Expectations of Nigerian Consumers of Electricity under a Post Privatization Era: Issues \& Perspectives" <www.nercng.org/index.php/ document-library/NERC-Presentations-Reports-and-Papers/The-Expectationsof-Nigerian-Consumers-of-Electricity-Under-a-Post-Privatization-Era-Issuesand-Perspectives-March-14-2014/> accessed 10 January 2015.

5 A. Eberhard and K. Nawaal Gratwick, "Light Inside: The Experience of Independent Power Projects in Nigeria", available at < www.gsb.uct.ac.za/files/ LightInside.pdf $>$ accessed 10 January 2015.

6 Y. Oke, Nigerian Electricity Law and Regulation (Law Lords Publications 2013) 318.

7 A. Iwayemi, "Investment in Electricity Generation and Transmission in Nigeria: Issues and Options" (2008) 1 IAEE Energy Forum 37, 37.

8 UNIDO, Independent UNIDO Country Evaluation: Federal Republic of Nigeria (UNIDO 2011) 54. 
intended to bring about access to energy services, meeting the energy needs and diversification. ${ }^{9}$ The intent of reforms is the enhancement of privatization and commercialization to create an avenue for a competitive energy market. ${ }^{10}$ Such a reform should accord to renewable energy opportunity for development. However, the legal framework in the Nigerian power sector does not provide the enabling environment for investors to explore renewable energy. ${ }^{11}$ In the absence of rapid government intervention, many countries with Nigeria inclusive will maintain this trend. ${ }^{12}$

The existing legal structures and framework in the electricity market do not place renewable energy at a competitive advantage. ${ }^{13}$ The progress in renewable energy deployment is not only dependent on the successful design of support measures but also on the framework of the electricity market and the interplay between the regulation of support for renewable energy and the market. ${ }^{14}$ In the context of Nigeria, there are many legal barriers to the successful utilization of renewable energy sources, which this article seeks to address.

There is overlapping roles and lack of clarity of purpose of institutions relevant to the promotion of renewable energy. The high cost of renewable energy projects, inadequate framework for funding, inability of consumers to pay for electricity, insufficient licensing duration, grid access and connection issues, variability of renewable energy and the challenges of forecasting and balancing obligations, and lack of adequate information on renewable energy in the Nigerian electricity market constitute major barriers to integration of renewable energy as part of Nigeria energy mix. This article, therefore, sets out the imperatives for renewable energy and analyses the barriers to their integration in Nigeria. It also offers suggestions on how the law may address the barriers.

9 M.T. Ladan, "Policy, Legislative and Regulatory Challenges in Promoting Renewable Energy in Nigeria" in R Mwebaza and LJ Kotzé (eds), Environmental Governance and Climate Change in Africa: Legal Perspectives (Institute for Security Studies 2009) 104.

10 N.K. Dubash, "Electric Power Reforms: Social and Environmental Issues “ in CJ Cleveland, Encyclopaedia of Energy (Vol. 2) (Elsevier Inc. 2004) 259.

11 See Ajayi and Ajayi (n 1) 64.

12 United Nations Environment Programme, Reforming Energy Subsidies: Opportunity to Contribute to Climate Change Agenda (United Nations Environment Programme, 2008) 9.

13 Oke (n 6) 312.

14 See F. Mormann, “Enhancing the Investor Appeal of Renewable Energy” (2012) 42 Environmental Law 681, 707. 
The overall argument put forward in this article is that the attendant legal barriers have not occasioned the utilization of renewable energy sources in Nigeria; setting out affirmative legal measures to address them and effective implementation of the measures will contribute extensively to the integration of renewable energy investment in the Nigerian power sector. Section 1 sets the context for the need to promote and address the barriers to renewable energy in the Nigerian power sector. Section 2 examines the imperatives for the promotion of renewable energy in Nigeria, while section 3 analyses the existing barriers to investment in renewable electricity. Section 4 offers solutions to addressing the barriers to renewable electricity in the country. Section 5 concludes the article.

\section{IMPERATIVES FOR THE RENEWABLE ENERGY}

Renewable energy utilization in Nigeria will contribute to meeting energy security and needs, mitigation of climate change and the promotion of economic development. According to the World Bank, "the growth in demand in the Nigerian power sector is expected to continue to increase by around 10 per cent per annum in the medium term, reaching 10,000 MW Megawatt (medium growth rate scenario) to 14,000 MW (high growth scenario) by the end of the decade". ${ }^{15}$ Deforestation through tree felling to meet basic household energy needs is prevalent. ${ }^{16}$ Self-generation using petrol and diesel engines is very common in Nigeria to counter the intermittent power supply. ${ }^{17}$

Nigeria is also contributing to environmentally damaging activities, particularly increasing its global share of greenhouse gas (GHG) emissions, as a result of the reliance on fossil fuel for electricity generation. ${ }^{18}$

15 World Bank, Nigeria-Nigeria Power Sector Guarantees Project (World Bank, Washington, DC 2014) <http://documents.worldbank.org/curated/en/2014/04/ 19391811/nigeria-nigeria-power-sector-guarantees-project $>$ accessed 10 January 2015.

16 Federal Ministry of Environment, Nigeria and Climate Change: Road to Cop15Achieving the best outcome for Nigeria (Federal Ministry of Environment 2009) 53.

17 M.O. Oseni, “Improving Households' Access to Electricity and Energy Consumption Pattern in Nigeria: Renewable Energy Alternative” (2012) 16 Renewable and Sustainable Energy Reviews 3967, 3974.

18 P.B. Eregha, "Sustainable Energy and Sustainable Development: Which Way Forward for Nigeria?" in A. Adenikinju, A. Iwayemi and W. Iledare, Green Energy and Energy Security Options for Africa: Proceedings of the 2012 Conference of the Nigerian Association of Energy Economics (Ibadan: Atlantis Books 2012) 304. 
The creation of a sustainable energy future, therefore, requires the diversification of Nigeria's energy potential to alternative energies such as renewable energy sources. ${ }^{19}$ Currently, the carbon emission profile from "solid, liquid, and gas fuels and gas flaring" in Nigeria is put at 0.5 metric tonnes per capita. ${ }^{20}$ There is the tendency that it will continue to rise should Nigeria continue its development along that current path without giving consideration to large-scale deployment of renewable energy.

The Nigerian electricity market is segmented into generation, transmission and distribution. ${ }^{21}$ At the inception of the electricity market in Nigeria, as in the case of most developing countries, the generation, distribution and transmission of electricity was seen as the responsibility of the government. ${ }^{22}$ The sector is being liberalized and unbundled to encourage private sector participation. ${ }^{23}$ The economy is generally open to private investors and there is no restriction on foreign enterprise investment. ${ }^{24}$ Foreign enterprises can invest in Nigeria upon registration with the appropriate authorities in Nigeria..$^{25}$ The mere fact that the law has granted private investors such an opportunity to invest in the power sector will not be sufficient for investors to venture into renewable energy without specifically addressing the challenges that can inhibit the promotion of renewable energy within the structure and governance of the electricity market.

19 S.O. Oyedepo, “On Energy for Sustainable Development in Nigeria” (2012) 16 Renewable and Sustainable Energy Reviews 2583, 2589.

20 World Bank, "CO 2 Emissions (metric tonnes per capita)" <http:// data.worldbank.org/indicator/EN.ATM.CO2E.PC/countries/NG-ZF$\mathrm{XN}$ ?display=default $>$ accessed 10 January 2015.

21 K Etim and A Oni, "Nigeria" in David L. Schwartz (ed.), The Energy Regulation and Markets Review (Law Business Research Ltd 2012) 200.

22 O. Onazi, "Reframing Public Goods: Human Rights, Community and Governance in the Third World" (PhD Thesis, University of Edinburgh 2010) 133.

23 Oke (n 6) 9.

24 See generally K.U.K. Ekwueme, “Nigeria's Principal Investment Laws in the Context of International Law and Practice” (2005) 49 (2) Journal of African Law 177, 177-206.

25 Companies and Allied Matters Act Cap C20 LFN 2004 ss 19 and 20; Nigerian Investment Promotion Commission Act Cap NI I7 LFN 2004, ss 17 and 20. 


\section{BARRIERS TO RENEWABLE ELECTRICITY INVESTMENTS}

This section seeks to elaborate the barriers to renewable energy investment in the Nigerian power sector. It shows that challenges have impeded the possible incorporation of renewable energy into the Nigerian energy system. It, therefore, makes a case for the development of a legal framework to address the challenges of promoting investment in renewable energy in the electricity sector.

\subsection{Overlapping Roles and Lack of Clarity of Purpose of Institutions}

A clear institutional framework for renewable energy is lacking in Nigeria. ${ }^{26}$ There are many institutions playing varied roles in the power sector. These institutions include the Energy Commission of Nigeria (ECN), Nigerian Electricity Regulatory Commission (NERC) and Federal Ministry of Power. The EPSR Act sets out in detail the regulatory functions of NERC, cutting across the activities of the power sector. NERC is charged with the responsibility of the promotion of competition and private sector participation in the power sector; establishing relevant operating codes, safety, security, and reliability and quality standards; providing appropriate consumer rights and obligations on the use of electricity services; licensing of electricity activities and monitoring of the operation of the electricity market. ${ }^{27}$

In discharging its responsibilities, NERC is required by law to consider the following: the creation, promotion and preservation of efficient industry and market structures and ensuring optimal utilization of resources for the provision of electricity services; maximizing access to electricity services through the promotion and facilitation of distribution systems to consumers; ensuring adequacy of electricity supply to consumers; ensuring that prices charged by licensees are sufficient to finance their activities and include reasonable earnings for efficient

26 S.O. Oyedepo, “Towards Achieving Energy for Sustainable Development in Nigeria” (2014) 34 Renewable and Sustainable Energy Reviews 255, 269.

27 ibid s 32 (1).

28 ibid s 32 (2).

29 Latham \& Watkins, "Nigerian Power Sector Reforms: Opportunities and Challenges for Investment" <www.lw.com/thoughtLeadership/nigeria-rampsup-power-sector-reforms> accessed 10 January 2015. 
operations; safety, security, reliability and quality of electricity of services in electricity generation and distribution to consumers; and ensuring that regulation is fair and balanced for licensees, consumers, investors and other stakeholders. ${ }^{28}$

NERC can also be referred to as the technical and economic regulator of the Nigerian power sector..$^{29}$ NERC is expected to facilitate efficiency, competition, and equity in the Nigerian power sector and among its stakeholders. ${ }^{30}$ From the examination of the functions of NERC, it can be deduced that the provisions are designed to create an atmosphere of comfort for IPPs, investors and their financiers. ${ }^{31}$

NERC can make regulations for the sector on matters within the powers and functions itemized. Section 96 (1) of the EPSR Act 2005 provides that NERC "may make regulations prescribing all matters which by this Act are required or permitted to be prescribed or which, in the opinion of the Commission, are necessary or convenient to be prescribed for carrying out or giving effect to" the EPSR Act 2005. The list of areas in which NERC could make regulations include administration of the affairs and proceedings of the NERC; matters relating to licencing; fees, levies, and other charges; "investments, assets, and properties, and the interest in such assets and properties, in connection with the electricity industry"; customer-related issues; resource procurement policies pertaining to licensees; regulation of rural electric schemes and investment; monitoring of market power monitoring, mitigation and enforcement; regulation of third party access granted by transmission and distribution licensees; imposition of fines and penalties on defaulters of the regulation. ${ }^{32}$

Apart from the NERC, the general policy direction of the electricity sector is the key responsibility of the Federal Ministry of Power, headed by a minister. The ministry issues general policy directions to NERC on

30 Y. Omorogbe, Why We Have no Energy (University of Ibadan Press 2008) 50.

31 K.D. Larson, 'Sparking a Spread? Regulatory Efforts to Stimulate Independent Power in Nigeria' (2008) 3. (2) Texas Journal of Oil, Gas, \& Energy Law 151, 159.

32 EPSR Act 2005, s 96 (2) (a)-(q). The NERC (Permits for Captive Power Generation) Regulations 2008; Regulations on Embedded Generation 2012; Independent Electricity Distribution Network (IEDN) Regulations 2012 are examples of the numerous regulations issues by NERC pursuant to its powers under s 96 of the EPSR Act 2005. See T. Oyewunmi, “International Best Practices and Participation in a Private Sector Driven Electricity Industry in Nigeria: Recent Regulatory Developments” (2013) 8 International Energy Law Review 306, 310 11. 
matters concerning electricity and overall system planning and coordination of the sector. ${ }^{33}$ The minister can make declarations for the initiation of a more competitive electricity market in the country by virtue of Section 24 of the EPSR Act $2005 .{ }^{34}$ NERC is under obligation to prepare and submit to the minister a yearly report that the sector has reached a stage warranting progress to a more competitive electricity market before the minister makes a formal declaration that the electricity market is competitive. ${ }^{35}$

It is required that the degree of privatization must be considered. ${ }^{36}$ There must be a sufficient number of potential competitive entities in order to check any abuse of the market. ${ }^{37}$ Furthermore, regard should be given to the existence of other preconditions, including necessary meter information and technologies that are required for the operation of a competitive electricity market. ${ }^{38}$ The minister in consultation with the president of Nigeria and the National Council on Privatization, having been satisfied that the electricity market in the country has attained a stage where a more competitive market ought to be established, will issue a declaration to that effect. ${ }^{39}$ Other functions of the minister include recommending to the president the approval of market rules developed by system operators. ${ }^{40}$

The Energy Commission of Nigeria (ECN) Act $1979^{41}$ established the ECN as the coordinating agency for energy matters in Nigeria. ${ }^{42}$ The ECN has the function of the strategic planning of energy; policy coordination and performance monitoring for the whole energy sector,

33 EPSR Act 2005, s 33.

34 B. Saidu, "Committing to Legal and Regulatory Reform: An Analysis of the Legal and Regulatory Framework of the Electricity Supply Industry in Nigeria" (2011) 29 (3) Journal of Energy \& Natural Resources Law 355-82, 360.

35 EPSR Act 2005, s 24 (2).

36 ibid s 24 (2) (a).

37 ibid s 24 (2) (b).

38 ibid s 24 (2) (c).

39 ibid s 24 (3). See Saidu (n 34) 360.

40 EPSR Act 2005, ss 20, 26 and 88. See also O Arowolo, "Licensing Electricity Business in Nigeria: Issues and Comments” (2006) 1 International Energy \& Taxation Law Review 29, 30.

41 Established by Act No. 62 of 1979, as amended by Act No.32 of 1988 and Act No. 19 of 1989 (Cap E10, Laws of Federation of Nigeria, 2004).

42 See I. Worika, "Energy Development and Utilization in Africa” in A.J. Bradbrook, R.L. Lyster, R.L. Otiinger and W. Xi, The Law of Energy for Sustainable Development (Cambridge University Press 2005) 354. 
setting guidelines on the utilization of energy; developing recommendations for the exploitation of new sources of energy. ${ }^{43}$ Within the ECN is the Department for Renewable Energy Sources established under the Act. ${ }^{44}$ There is no linkage of the ECN with NERC and the Federal Ministry of Power in the EPSR Act 2005. The express relevance of the $\mathrm{ECN}$ is currently questionable. Could it really be referred to as the coordinator of the energy sector strictly speaking? There is a possibility of overlap of functions and one would wonder which should prevail over the other in terms of giving directives to the sector.

The absence of a clear coordination of the institutions for the development of renewable energy in Nigeria has negatively impacted on its growth.$^{45}$ Redefining the legal duties of the institutions may be desirable so that investors are not confused. They should be able to identify who plays what role in the sector. For example, in participating in demonstration projects, should the action for initiation of such projects be directed to the Federal Ministry of Power or to ECN? Even the Federal Ministry of Environment has claimed it has initiated and implemented projects on renewable energy in Nigeria. The projects include the construction of grid-connected solar PV plants in the six geopolitical zones of Nigeria and wind energy projects in six states. ${ }^{46}$ It also claimed to have initiated 'Waste to Energy Projects' in six states. ${ }^{47}$

The Federal Ministry of Environment is the coordinating ministry on environmental matters. As part of the approval process for any energy project, it must conform to the Environmental Impact Assessment Act 1992 as contained in Section 2 of the Environmental Impact Assessment Act $1992 .{ }^{48}$ In the same vein, Section 70 of EPSR Act makes the provision of an environmental impact assessment, approved by the Federal Ministry of Environment a precondition for the grant of generation, transmission, system operation, distribution or trading licence. ${ }^{49}$ It would therefore be

43 ECN Act 1979, s 5.

44 ibid s 2(b).

45 E.L. Efurumibe, "Barriers to the Development of Renewable Energy in Nigeria" (2013) 2 (1) Scholarly Journal of Biotechnology 11, 12.

46 The Federal Ministry of Environment's Renewable Energy Programme, "Investment Areas" <http://renewableenergy.gov.ng/invest/investment-areas/> accessed 10 January 2015.

47 ibid.

48 Saidu (n 34) 362.

49 ibid. 
appropriate for the Ministry to confine itself to its role while more specialized governmental agencies are charged with the task of initiating renewable energy projects.

\subsection{High Cost of Renewable Energy Projects}

A major drawback to the development of renewable energy in the Nigerian power sector is the expensive technologies needed. ${ }^{50}$ Furthermore, renewable energy technologies are still very new to Nigeria. ${ }^{51}$ The up-front capital cost for renewable energy in the country is higher than that of conventional energy projects. ${ }^{52}$ Investors are less likely to invest in renewable energy sources, knowing that they may not be able to generate profit because of the high start-up capital. Bongaerts and Dogbe argues that, generally, electricity from renewable energy sources is more expensive than conventional energy sources and that fiscal or incentive mechanisms are needed to enable them to play a meaningful role in the total energy balance. ${ }^{53}$ On the need to support solar energy, the Lagos State Ministry of Energy and Mineral Resources observe that: "Traditionally, the cost of a solar installation may be 3-5 times the cost of deploying a fossil fuel fired solution of similar capacity". ${ }^{54}$

There are many reasons for the higher cost. For example, mechanisms for storing the energy sources due to their variability in supply are also expensive. ${ }^{55}$ Investors in Nigeria will have to arrange for such storage batteries, which will result in an increase in the unit cost of electricity

50 S. Amadi, "Ethics and Values in Sustainable Development" <www.nercng.org/ index.php/nerc-documents/func-startdown/267/> accessed 10 January 2015.

51 Kalu Uduma and Tomasz Arciszewski, "Sustainable Energy Development: The Key to a Stable Nigeria” (2010) 2 Sustainability 1558, 1565.

52 National Planning Commission (NPC), Report of the Vision 2020 National Technical Working Group on Energy Sector (NPC, 2009) 57.

53 J.C. Bongaerts and G Dogbe, "Optimal Institutional Arrangements and Instruments for the Promotion of Energy from Renewable Sources" in M. Faure, J. Gupta and A. Nenjes (eds.), Climate Change and the Kyoto Protocol: The Role of Institutions and Instruments to control Global Change (Edward Elgar Publishing Limited 2003) 201.

54 Lagos State Ministry of Energy and Mineral Resources, Consultation Document for the Development of a Renewable Energy Policy (Lagos State Ministry of Energy and Mineral Resources 2012) 14.

55 N. Farquhar, “Energy, Security, Climate: Converging Solutions” (2009) 29 (1) Journal of Land, Resources E Environmental Law 1, 10-11.

56 M.S. Adaramola, "Viability of Grid-connected Solar PV Energy System in Jos, Nigeria” (2014) 61 Electrical Power and Energy Systems 64, 64. 
generation. ${ }^{56}$ The effectiveness of solar energy will be dependent on the availability of the sun and the way it can be converted into energy. ${ }^{57}$ Investors and lenders are usually unwilling to finance projects, which by their nature will result in negative cash flow or value fluctuations. ${ }^{58}$ Therefore, investors will not divert their funds to invest in projects that are capital intensive until there is the assurance that they will recoup their investment.

The perception of the government is similar to that of private investors because of the cost involved in the development of renewable energy projects. ${ }^{59}$ A proactive approach should have been the case. It has been well established within the context of traditional macroeconomic theory that where there is inadequacy of incentives, leading to shortage of revenue and profit, companies will not be encouraged to enter the market and invest as they are not likely to recoup their investment. ${ }^{60}$ Applying the theory to the development of renewable energy sources, which by their nature require technologies that involve high capital outlay, financial barriers will continue to affect the integration of renewable energy into the energy market. ${ }^{61}$

As confirmed by the Global Environmental Facility (GEF), renewable energy projects involve "a different financing profile with typically much higher upfront capital costs. This makes them more sensitive to the cost of capital, which in a country like Nigeria, is high due to additional informational, technical, regulatory, financial and administrative risks, which such projects entail". ${ }^{62}$ Thus, in a cash-constrained economy such as Nigeria, due to high cost, monies may be used to meet other competing investments instead of venturing into renewable energy projects. ${ }^{63}$

57 K. Hogg and R O 'Regan, "Renewable Energy Support Mechanism: An Overview" in M Bonass and M Rudd, Renewables: A Practical Handbook (Globe Business Publishing Limited 2010) 33.

58 UNEP, Financial Risk Management Instruments for Renewable Energy Projects (United Nations Publication, 2004) 13.

59 See Oke (n 6) 318.

60 J.R. Wiener, "Sharing Potential and the Potential for Sharing: Open Source Licensing as a Legal and Economic Modality for the Dissemination of Renewable Energy Technology" (2006) 18 The Georgetown International Environmental Law Review 277, 292.

61 ibid 292.

62 GEF, Promoting Low Carbon Energy Solutions in Nigeria Energy/Power Supply, available at <www.thegef.org/gef/project_detail ?projID $=5345>$ accessed 10 January 2015.

63 Efurumibe (n 45) 12. 


\subsection{Inability of Consumers to Pay for Electricity}

The inability of consumers to pay for electricity is a major concern in Nigeria. Most consumers cannot afford the price of electricity. This situation is further aggravated by the fact that there is a culture in Nigeria that public goods are not meant to be paid for by the citizens. ${ }^{64}$ The rate of poverty in Nigeria is high. Many consumers cannot afford to pay for renewable energy at a price enabling cost recovery. This situation distinguishes Nigeria from developed economies where consumers are able to afford the cost of electricity. ${ }^{65}$ The main design issue in the support for renewable energy is who pays the incremental cost. ${ }^{66}$ In developed economies the cost of funding investment in renewable energy is socialized by passing it to the consumers through electricity consumer bills. ${ }^{67}$

Therefore, bearing the cost of the decarbonisation of the energy sector is ultimately passed to the consumers in developed economies. ${ }^{68}$ The price of electricity is a determinant factor in attracting investors. If the price of electricity is such that consumers cannot afford it, the demand will fall. This, therefore, makes pricing the most sensitive aspect of the power sector reform. ${ }^{69}$ It could be argued that cost reflective pricing, as canvassed, has an impact on the poor and may raise political challenges in developing

64 S. Amadi, "The Expectations of Nigerian Consumers of Electricity Under a Post Privatization Era: Issues \& Perspectives" <www.nercng.org/index.php/ document-library/NERC-Presentations-Reports-and-Papers/The-Expectationsof-Nigerian-Consumers-of-Electricity-Under-a-Post-Privatization-Era-Issuesand-Perspectives-March-14-2014/> accessed 10 January 2015.

65 See K. Huhta, J. Kroeger, T. Oyewunmi and P. Eiamchamroonlarp, "Legal and Policy Issues for Capacity Remuneration Mechanisms in the Evolving European Energy Market" (2014) 23 European Energy and Environmental Law Review 76-88, 86.

66 P. Meier, M. Vagliasindi, M. Imran, A. Eberhard and T. Siyamlapitiya, The Design and Sustainability of Renewable Energy Incentives: An Economic Analysis (World Bank 2015) 4.

67 ibid.

68 See C. Banet, Tradable Green Certificates under EU Law: The Influence of EU Law on National Support Schemes for Renewable Electricity Generation (Ph.D Thesis, University of Oslo 2012) 35-36.

69 B. Adaralegbe, "Foreign Private Participation in the Electricity Sector of Developing Countries: What Works? An Examination of Nigeria's Reformed Electricity Sector" (2009) 10 (6) The Journal of World Investment E Trade 1, 22. 
countries such as Nigeria. The government in 2012 removed the subsidies for petroleum products in Nigeria. ${ }^{70}$ The effect of the removal was a nationwide protest. ${ }^{71}$ This resulted in the government changing its decision. ${ }^{72}$ According to the United Nations Environmental Programme (UNEP):

Ultimately, renewable energy project and technology incentives will have to be borne by either tax payers or energy consumers. This raises financial and political difficulties in developing countries where large parts of the population are poor and cannot be burdened with the additional costs of renewable energy deployment. ${ }^{73}$

The poverty situation in developing economies, including Nigeria, places the government in a situation of creating subsidies for electricity at a price that is lower than the cost of the electricity supplied to consumers. ${ }^{74}$ Government sees it as its responsibility to provide electricity at an affordable cost to consumers, owing to the economic situation. Under the arrangement, utilities lack adequate income to operate and improve their services. ${ }^{75}$ The major challenge, therefore, is how the government will strike a balance in meeting the costs of the investors and that of the consumers. This could have been actualized through the Power Consumer Assistance Fund (PCAF) provided for under the EPSR Act 2005 to subsidize the cost of electricity to underprivileged consumers. ${ }^{76}$ However, since the effecting of the EPSR Act 2005, the PCAF has not been set up as required. The PCAF would enable the government to give

70 D. Gielen, A. Miketa and B. Merven, "Power Supply Scenarios for the ECOWAS Region" in DV Ferrenbach (ed), Renewable Energy in West Africa: Status, Experiences and Trends (ECOWAS Centre for Renewable Energy and Energy Efficiency, Renewable Energy Department, Canary Island Institute of Technology and Economy and Business Area, CASA África 2012) 50.

71 N. Moyo and V. Songwe, "Removal of Fuel Subsidies in Nigeria: An Economic Necessity and a Political Dilemma" <www.brookings.edu/research/opinions/ 2012/01/10-fuel-subsidies-nigeria-songwe> accessed 10 January 2015.

72 Ernst \& Young, Renewable Energy Country Attractiveness Index (Ernst \& Young 2014) 20.

73 UNEP, Financing Renewable Energy in Developing Countries: Drivers and Barriers for Private Finance in Sub-Saharan Africa (UNEP 2012) 48.

74 Adaralegbe (n 69) 22.

75 See M. Abdi, "Will Electricity Privatization and Structural Reforms of Small Power System Developing Countries Lead to Efficiency Delivery of Electricity?" CEPMLP Annual Review 2002, cited in Adaralegbe (n 69) 22.

76 EPSR Act 2005, s 83. 
subsidies to consumers who cannot afford electricity.

\subsection{Inadequate Framework for Funding}

The absence of a comprehensive framework for financing renewable energy is a major obstacle to the development of renewable energy projects in Nigeria. ${ }^{77}$ In a capital constrained economy such as Nigeria, where there is high competition for the scarce capital, funding renewable projects is challenging. ${ }^{78}$ Investment in renewable energy is faced with challenges in the business environment in Nigeria, which is characterized by low credit ratings and low availability of capital for investment. Financing new renewable energy projects could be by loans, with high interest rates and strict covenants and other securities. In a country such as Nigeria, the situation has been complicated by the state of local financing in the financial services sector. The then Minister for Power, Professor Pat Nebo, while signing a US $\$ 350$ million agreement with GE for investment in renewable energy power projects admitted that lack of access to funds has discouraged diversification. ${ }^{79}$ The Nigerian financial sector is still evolving. ${ }^{80}$

The Zungeru Hydropower project, which is funded by a robust arrangement, is clear evidence that progress can be made in renewable energy in Nigeria but that it will depend on a favourable funding arrangement. Under the loan arrangement for the project, which is worth US\$1.3 billion, the Export-Import Bank of China will fund 75 per cent of the projects under a loan with duration of 20 years and an interest rate of 2.5 per cent with a grace period of seven years. ${ }^{81}$ There is a general perception of risk in funding renewable energy projects in Nigeria. ${ }^{82}$ All projects, whether for renewable energy or conventional energy, have

77 J.A. Omojolaibi, "Financing the Alternative: Renewable Energy in the Nigerian Economy" in Adenikinju, Iwayemi and Iledare (n 18) 69.

78 NPC (n 52) 57.

79 O. Nnodim, "FG signs N55bn Renewable Energy Agreement with GE" $<$ www.punchng.com/news/fg-signs-n55bn-renewable-energy-agreement-withge- $2 />$ accessed 10 January 2015.

80 See A.T. Popoola, "The Challenge of Financial Infrastructure in Nigeria” $<$ www.nigeriadevelopmentandfinanceforum.org/PolicyDialogue/ Dialogue.aspx?Edition=101> accessed 10 January 2015.

81 "Nigeria signs Deal with China Exim Bank for 700-MW Zungeru Hydropower Project" <www.hydroworld.com/articles/2013/09/nigeria-signs-deal-with-chinaexim-bank-for-700-mw-zungeru-hydropower-project.html> accessed 10 January 2015.

82 Oke (n 6) 318. 
certain risks associated with them. There are some risks, which have been generally recognized to affect the deployment of renewable energy projects. These risks include project level risks as well as regulatory, financial and market, legal, political and force majeure risks. ${ }^{83} \mathrm{On}$ regulatory risks, licences will be required to be issued for the projects. This will be by application following the prescribed form to the NERC. There may be delays or concern that the licence may not be granted by the authorities. For example, there is the requirement of the applicants to comply with the provisions of the Environmental Impacts Assessment Act 1992 before the grant. ${ }^{84}$ It may not in all cases be predictable whether such licence would be granted or meet the specification.

The financial risk may be in relation to securing loans to finance the project, and equipment may turn out to be very expensive due to inflation. There is also the political risk, which may be due to a change in government or of government officials in Nigeria. Measures put in place may be abandoned as a result of the changes. Their impact on the funding of renewable energy projects has continued to make investment in renewable energy very low in Nigeria. ${ }^{85}$ However, the risk profile of renewable energy projects is higher. Where technologies have not been proven to have high performance or their track records are limited, they are seen by investors as risky. ${ }^{86}$ This is the case with Nigeria where there is the perception that the technologies may not be reliable. ${ }^{87}$ This can create some level of scepticism in the mind of potential investors. Overall, there is a performance risk in relation to renewable energy projects. There is the perception that most of these technologies have not been tested. ${ }^{88}$

Regulatory risk could be in relation to planning approval and

83 D. de Jager and M. Rathmann, "Policy Instrument Design to Reduce Financing Costs in Renewable Energy Technology Projects” <www.ecofys.com/files/files/ retd_pid0810_main.pdf $>$ accessed 10 January 2015.

84 Environmental Impact Assessment Act 1992, s 2; EPSR Act 2005, s 70.

85 F. Asu, "Nigeria Lags in Renewable Energy Investment as Peers Lead Charge" (BusinessDay 9 May 2013) <http://businessdayonline.com/2013/05/nigeria-lagsin-renewable-energy-investment-as-peers-lead-charge/> accessed 10 January 2015.

86 Hogg and O’Regan (n 57) 33.87 A.O. Aliyu and J.Y. Bawa, "Identifying Market, Institutional and Financial Barriers to the Implementation of Renewable Energy Technologies in Nigeria" in Adenikinju, Iwayemi and Iledare (n 18) 61.

87 A.O. Aliyu and J.Y. Bawa, "Identifying Market, Institutional and Financial Barriers to the Implementation of Renewable Energy Technologies in Nigeria" in Adenikinju, Iwayemi and Iledare (n 18) 61.

88 Efurumibe (n 45) 12. 
licensing. Investors could be wary of the likelihood that they may not get the requisite approval. Even when the approval is granted, they may be confronted by challenges from individuals and communities regarding the location of renewable energy projects in a given area. The high cost of a renewable energy project is also a risk. ${ }^{89}$ The perceived risk has made banks prefer investing in conventional energy sources instead of renewable energy. ${ }^{90}$ Ideally, before funding renewable energy projects, there would be need for proper due diligence to be conducted in relation to the existing risks identified above, but the banking sector does not have a clear understanding of the nature of due diligence required for renewable energy projects. ${ }^{91}$ The promoters of the United Nations Development Programme/Bank of Industry programme for renewable energy rightly identified "finance and funding as the major factor hindering the development of renewable energy in Nigeria". ${ }^{92}$

\subsection{Licensing Duration as an Impediment}

The duration of the grant of licence in Nigeria is ten years. Thereafter, the licence can be extended for a further period of five years. It is contended that the period of the grant of the licence may not be sufficient for investors to recoup their investment and make more profit before the expiration of their licenses. Renewable energy projects naturally will require a long-term period before they become economically viable. According to the Lagos State Ministry of Energy and Mineral Resources, "... the cost of the solar installation can be recovered over its useful life, usually 20-25 years; it is possible, with the right type of financing, to spread the cost of deployment over many years". ${ }^{93}$ The argument for the use of renewable energy deployment in Nigeria will be that though they

89 Bank of Industry, “Access to Financing Renewable Energy in NigeriaIntroduction of Different Models and Requirements" < http://nigeria.ahk.de/ fileadmin/ahk_nigeria/Renewable_Energy Access_to_Financing_ Nigeria_German_Business_Council.ppt> accessed 10 January 2015.

90 L. Baker, "Facilitating whose Power? IFI Policy Influence in Nigeria's Energy Sector" <www.brettonwoodsproject.org/wp-content/uploads/2014/04/ Nigeria.pdf $>$ accessed 12 January 2015.

91 Asu (n 85).

92 M. Eboh, "Nigeria: Funding Hinders Development of Renewable Energy" The Vanguard (18 June 2013) <http://allafrica.com/stories/201306180898.html> accessed 10 January 2015.

93 Lagos State Ministry of Energy and Mineral Resources (n 54) 14.

94 Onazi (n 22) 191. 
are initially expensive, they become cheaper in the long run. ${ }^{94}$ However, when it is time to reap the benefit of the project, the licence may no longer be in operation if not renewed. Even when the licence is renewed, the 15 -year period granted may still be insufficient for investors to reap their investment.

Therefore, a period of 20-25 years would have ordinarily been the better option to be considered. This will continue to contribute to the impediments to investment in renewable energy projects until there is an amendment of the EPSR Act 2005 to grant a longer duration for the grant of a licence. The licensing duration should at least be commensurate with the lifespan of the project to enable investors in renewable energy to have sufficient time to construct the project and derive the revenue accruing from it.

\subsection{Grid Access and Connection Issues}

The situation for the entry of renewable energy into the Nigerian market is very challenging in that access to network and the grid operates on the principle of non-discrimination. ${ }^{95}$ There is no distinction of energy sources or whether priority should be accorded to a particular energy source. ${ }^{96}$ The dispatching of generation and determination of the interconnection of electricity is the function of the transmission system operator, on a non-discriminatory basis. That the cost of electricity from renewable energy sources will be lower than that of fossil fuel will be determined by factors such as the support mechanism provided as well as the grid connection procedure and the price of transmission. ${ }^{97}$ The absence of provision for priority connection of renewable energy to the grid continues to remain a major barrier in Nigeria. ${ }^{98}$

Investors will want to guarantee that the renewable energy they generate will be connected to the grid. Renewable energy generators will be discouraged if, having the required support, they are unable to reap

95 EPSR Act 2005, s 82 (4) and (5).

96 B. Irukera and I Isiekwena, “Nigeria” in E.H. O’Donnel, Electricity Regulation (Getting The Deal Through, Law Business Research Limited 2009) 156.

97 G. Bellantuono, "Comparing Regulatory Decision-Making in the Energy Sector” (2010) 1 (2) Comparative Law Review, 1, 41.

98 K.M. Usman, A.H. Iza and J.O. Ojosu, "Renewable Energy Financing: Towards a Financing Mechanism for Overcoming Pre-Commercialization Barriers of Renewable Energy Financing System in Nigeria” (2012) 3 (4) International Journal of Scientific E Engineering Research, 1, 3. 
the benefit of having the electricity they generate connected to the grid.

\subsection{Variability of Renewable Energy, Forecasting and Balancing Obligations}

The market is evolving and Nigeria will get to a stage of a competitive electricity market where there will be a volatile spot market, where cash will be exchanged for immediate delivery of electricity. ${ }^{99}$ The producers of renewable electricity will be faced with difficulty in the sales of electricity in the market where the trade in electricity is a forward market under an arrangement where the producer will supply electricity to the system operator on an interval of five minutes on a day ahead. ${ }^{100}$ The producer is expected to fulfil the obligation on the output agreed to be made available.

If balancing obligations are introduced, then even where producers of renewable energy gain physical access to the grid and the electricity market, they will encounter considerable difficulties selling their electricity in the wholesale electricity market because of balance and imbalance settlement challenges. ${ }^{101}$ Failure to do that implies that the system operator must be paid compensation by the electricity producer for the imbalance in the settlement services that were used to meet the obligation of supplying the output. Since there could be fluctuation in renewable energy sources, which may not be subject to accurate prediction, they have to bear the cost of imbalances. ${ }^{102}$ This would constitute a serious market risk for renewable energy, thereby placing producers at a disadvantage with fossil fuel sources that are largely stable. ${ }^{103}$

\subsection{Lack of Adequate Information on Renewable Energy in the Market}

99 A. Oni, The Nigerian Electric Power Sector: Policy, Law, Negotiation Strategy, Business (Carmel and Sharon, 2013) 237.

100 F. Mormann, "Requirements for a Renewables Revolution” (2011) 38 Ecology Law Quarterly 903, 923-24.

101 ibid.

102 ibid.

103 A similar situation exists in Britain where penalties have been imposed for “intermittent and unreliable generation." See G Wood and S Dow, "What Lessons have been Learned in Reforming the Renewables Obligation? An Analysis of Internal and External Failures in UK Renewable Energy Policy” (2011) 39 Energy Policy 2228, 2237.

104 See R. Cervigni, J.A. Rogers, and M. Henrion (eds.), Low-Carbon Development Opportunities for Nigeria (World Bank 2013) 103-4. 
The country lacks sufficient data and information on renewable energy. ${ }^{104}$ The energy statistics in Nigeria are not up to date or accurate. ${ }^{105}$ There will be a need to update these statistics. The GEF recognized that information on potential sites as well as public awareness are lacking. ${ }^{106}$ The various agencies in the country will need to work in conjunction with one another to improve the country's energy statistics. There should be sufficient data from both renewable energy and conventional energy sources, which should be reviewed from time to time. There will be a need for governmental institutions relevant to the power sector to work with the National Bureau of Statistics to ensure that viable energy statistics are available and adequate. ${ }^{107}$ All these are essential because energy statistics should be factored in when designing the law for the scheme.

Insufficient or false information can impede public support for the deployment of renewable energy. This lack of public support, in turn, makes it less attractive for policy makers to adopt strong legislation to foster their deployment. Particularly, in developing countries, past experiences with early models of solar and wind technologies have led to a bias against these technologies. ${ }^{108}$ Creating some level of public awareness of the importance of renewable energy in Nigeria will enhance its promotion because lack of awareness is a major drawback. ${ }^{109}$ Consumers and investors need to be aware of the potential benefit of renewable energy to explore them. ${ }^{110}$

Likewise, bankers will also need some level of familiarity to be confident in financing renewable energy projects. ${ }^{111}$ Recently, Mr Patrick Mgbenwelu, the director and head of a leading financial institution in

105 S.U. Yamusa II and A.H. Ansari, "Renewable Energy Development in Two Selected African Countries: An Overview and Assessment” (2013) 2 Renewable Energy Law and Policy Review 151, 153.

106 GEF, Scaling up Small Hydro Power (SHP) in Nigeria <www.thegef.org/gef/ project_detail?projID=5375> accessed 10 January 2015.

108 International Energy Agency, Renewable Energy: Policy Considerations for Deploying Renewables (OECD/IEA 2011) 38.

109 Y.S. Mohammed, M.W. Mustafa, N. Bashir and A.S. Mokhtar, "Renewable Energy Resources for Distributed Power Generation in Nigeria: A Review of the Potential” (2013) 22 Renewable and Sustainable Energy Reviews 257, 266.

110 See A. Nogee, S. Clemmer, B. Paulos and B. Haddad, Powerful Solutions: 7 Ways to Switch America to Renewable Electricity (Union of Concerned Scientists 1999) 18-19.

111 E. Martinot, A. Chaurey, D. Lew, J.R. Moreira and N. Wamukonya, "Renewable Energy Markets in Developing Countries” (2002) 27 Annual Review of Energy and the Environment 309, 335. 
Nigeria, FBN Capital, was of the view that "the government might have to look to the private sector and international banks for funds to develop its renewable energy, as a lot of banks in the country do not understand the dynamics for financing that type of project". ${ }^{112}$

\section{ADDRESSING THE BARRIERS}

This section proposes the legal measures to address barriers to adopting renewable energy. It will specifically address the challenges of investment in renewable energy in the Nigerian power sector.

\subsection{Redefining the Roles of Institutions Relevant to Renewable Energy}

A challenge identified as hindering the entry of renewable energy into the electricity market is the lack of coordination and clarity within the institutions relevant to the promotion of renewable energy. The operation of renewable energy support schemes will require the existence of an institutional framework. An examination of the various institutions relevant to the power sector indicates that there are many agencies playing varied and converging roles. There is a need for harmony among the respective government agencies. The roles of each of the agencies should be clearly spelt out. It will be important that the role of the regulator, NERC be strengthened in the implementation of incentives under the tariff scheme in operation. The Energy Commission of Nigeria would also have to be involved in the promotion of renewable energy through the introduction of demonstration projects and programmes targeted at promoting the use of renewable energy in accordance with its mandate. Its role can be increased in the area of the enhancement of renewable energy generation programmes. The ministry should continue to carry out a supervisory role of ensuring that NERC performs its statutory functions.

\subsection{Establishing Robust Framework for Funding}

There is a need for the development of robust framework for funding renewable energy projects. Apart from the various commercial banks, there are specialized banks, which could have been used in funding

112 Asu (n 85). 
renewable energy projects. The National Agriculture Bank can offer support for the development of biomass feedstock for production of electricity from biomass sources. The Bank of Industry can be utilized to create funding opportunities for renewable energy projects, through reduced interest loans and grants. The Central Bank of Nigeria is also a good machinery for funding renewable energy projects, if it exercises its developmental functions under section 31 of the Central Bank of Nigeria Act 2007 to create funding for renewable energy projects. ${ }^{113}$ The government would rather direct funding to the development of oil and gas. ${ }^{114}$ Thus, the law should strengthen funding agencies in Nigeria to direct more funds to renewable energy projects.

With the coming into operation of the Nigerian Sovereign Wealth Investment Fund by virtue of the Nigeria Sovereign Investment Authority Act 2011, the fund can be used in meeting investments, which include promoting the development of critical infrastructure such as power generation, distribution and transmission. ${ }^{115}$ It may be contended that part of the fund could be specifically directed to promoting investment in renewable energy projects. This could create an avenue for robust funding through giving priority to renewable energy projects under a clear legal framework. Thus, the Act establishing the Fund provides that: "All ownership interest in the Authority shall be held by the Federal Government State Government, Federal Capital Territory and Local Government and Area Councils or the Federation on behalf of the people of Nigeria". ${ }^{116}$ It will receive, manage and invest in a diversified portfolio of medium and long-term revenue of the levels of government to 'prepare for the eventual depletion of Nigeria's hydrocarbon resources for the development of critical infrastructure in Nigeria that attracts and supports foreign investment, economic diversification, growth and creation in

113 The sum of N300 billion has been earmarked for funding power and airline projects under the Central Bank of Nigeria Guidelines on N300 billion Power and Airline Intervention Fund 2011. Substantial amount of the fund could be directed in funding renewable energy projects.

114 See Presidential Task Force on Power, Roadmap for Power Sector Reform (Presidential Task Force on Power 2010) 36.

115 See Nigeria Sovereign Investment Authority Act 2011, s 41(1).

116 ibid s 29 (2).

117 Explanatory memorandum to the Nigeria Sovereign Investment Authority Act 2011. 
Nigeria; and for related matters'. ${ }^{117}$

\subsection{Framework for subsidizing the Cost of Electricity for Underprivileged Consumers}

The ideal trend in a competitive electricity market is one in which the consumers should bear the cost of energy services. However, Nigeria as a developing country with a very high percentage of poor people will require that the burden of electricity is not placed on the consumers. The consumers cannot bear the extra cost of generation of electricity from renewable energy. In this study, the Power Consumer Assistance Fund (PCAF) was discussed as one of the funds established to subsidize the amount paid by underprivileged consumers. However, to date, the fund is yet to be implemented. Steps should be taken to implement the fund by putting in place a regulation for the operation of the fund. In the same vein, the funding for renewable energy through a fund established for such a purpose should be used to reduce the burden on consumers.

\subsection{Extension of Licensing Duration}

The duration of the grant of licence under the EPSR Act 2005 will need to be extended to span beyond the period of the duration of the tariff. The grant in the first instance is for 10 years, which is subject to renewal for another period of five years. NERC is not under an obligation to extend the licence after it has elapsed. The contention has been that the period does not seem to be in consonance with the payback period for renewable energy investment. A longer duration for the grant is important. Until the law is reviewed to extend the duration for the grant of licences, the grant of the licence would significantly undermine investors' confidence. The EPSR Act 2005 should, therefore, be amended to extend the duration for the grant of licence for a period of 20 years, which can further be renewed for a definite period.

\subsection{Providing Priority Connection and Access to Electricity Network}

Nigeria should include priority access and connection. The Electric Power Sector Reform (EPSR) Act 2005 will need to be amended to provide for favourable connection and priority access to the network for renewable electricity. A major challenge identified in the thesis that has militated against the integration of renewable energy in the Nigerian electricity market is non-discrimination in the connection of electricity to the grid. Electricity generated from renewable energy is not granted priority access 
to the grid.

\subsection{Exclusion of Renewable Electricity from Forecasting and Balancing Obligations}

Where the law is such that renewable energy will be subject to forecasting and the balancing rules in the market, their use will be discouraged unless the rules are tailored as far as possible to accommodate renewable energy intermittency. Excluding renewable energy generators from the obligations is an important measure; otherwise investors may be discouraged to enter the market because of the likelihood of being penalized for not meeting the obligation.

\subsection{Framework for Information on Renewable Energy in the Market}

It was found that lack of information is a barrier to the entry of renewable energy into the Nigerian electricity market. The publication of the progress report made on the success of the scheme should be publicly available. Information will contain the number of investors in the market, the amount of electricity generated from each of the renewable energy sources, the amount of funding expended in each financial year, and any other relevant information that will encourage investors to explore the Nigerian electricity market for investment in renewable energy. Legal obligations to produce a report and supply the data for renewable energy will need to be created. NERC should be charged with giving adequate progress report on the promotion of renewable energy. The ECN's role should be strengthened to give robust information on the renewable energy potential in the country and the general development made in integrating renewables in the power sector.

There could be more effort to work with specialized multilateral agencies such as the World Bank, UNEP, International Renewable Energy Agency (IRENA) and a host of other organizations to develop capacity on information gathering. Research development and demonstration would be very instructive. The institutions could continue to thrive in the development of the Nigerian renewable energy resource base. Institutions of higher learning in the country also have much to contribute to the process. Capacity building can also be used in enhancing data collection and provision of information in respect of renewable energy potential and installed capacity. The current initiative between the Bank 
of Industry and UNDP on access to the renewable energy programme is a welcome development that can be built upon by the government. ${ }^{118}$

Awareness would be required to boost the promotion of renewable energy projects in Nigeria. Companies across the world have been involved in various forms of ethical funding for the purpose of environmental protection where they are aware of the importance of renewable energy. Where environmental concerns and the role of renewable energy are brought to the fore of the public's attention, companies could by virtue of corporate social responsibility invest in renewable energy projects as a means of their contribution to mitigating the consequential effects of climate change. ${ }^{119}$

\section{CONCLUSION}

The challenges of incorporating renewable energy in the electricity mix have shown that it is placed at a competitive disadvantage when compared to electricity generated from oil and gas. There is lack of clarity of purpose and functions of the institutions meant to promote renewable energy. Investors are reluctant to invest in renewable energy projects because of high cost. There is also the challenge of getting funding for renewable energy projects. The duration of licences granted is not sufficient for the purpose of investment. The lack of priority for renewable energy remains a major legal challenge as the electricity market in Nigeria evolves. The law fails to create an exception for renewable energy.

Another related challenge is future trading arrangements and the need to meet forecasting and balancing obligations. The lack of adequate information on the role of renewables in the market is also a major challenge. The above challenges confirm the need for the development of

118 The overall objectives of the programme are set out as: "to build the capacity of: (i) MSMEs (Medium and Small-scale Enterprises) to incorporate renewable energy options either as a business in and of itself, or as service for business development; (ii) Financial institutions to increase investment in renewable energy, through better understanding and assessing of credit and financing risks of renewable energy investments and services; and (iii) Government to develop and implement renewable energy policies and regulatory frameworks that will facilitate RE options for MSME development in Nigeria”. See Bank of Industry, "BOI/UNDP Access to Renewable Energy Programme" <www.boinigeria.com/ file/boiundp.pdf $>$ accessed 10 January 2015.

119 See M. Bonass, “Why Renewable Energy?” in Bonass and Rudd (n 57) 17-18. 
a legal framework as a solution for resolving the problems as canvassed in the article. This will therefore call for sui generis rules for renewable energy within the current legal framework in the Nigerian power sector.

There is however implementation challenge which may operate as barrier to practical realization of the above proposals. The challenge, which the renewable energy sector over the world has faced, is that they depend largely on support from the government. The inability of renewable energy to make the required contributions to the Nigerian power sector can be attributed to the absence of political will and commitment. Building political will and commitment to the promotion of renewable energy is very important. "Committed political leadership" can foster development, as it constitutes an integral aspect in enhancing support for progress in renewable energy. ${ }^{120}$ Nigeria has always had the challenges of implementation of laudable laws and policies. For example, an area, which Nigeria has been lacking in, is the implementation of laws could be seen in relation to environmental laws in the oil and gas industry. ${ }^{121}$ It is contended here that the challenge of environmental legislations in Nigeria today is not the absence of a robust legal framework but lack of effective measures of implementation. ${ }^{122}$

Furthermore, for renewable energy to be successfully integrated into the Nigerian electricity sector there must be a legal framework spelling out sufficient support for it and addressing the challenges inhibiting its entry into the electricity market. This article however has taken a "forward- looking approach". To this end, there are incentives, which accrue to the government in promoting renewable energy. The economic prosperity of the country should be the major concern of any government that wants the people's approval, and renewable energy may offer an important measure towards the realization of developmental objectives.

In addition, the importance of renewable energy to climate change mitigation could be seen as part of the incentives which will promote environmentally sound measures. In the quest for a favourable and clean environment among nations, the use of renewable energy will enhance

120 R. Strange, “Weaving a Tangled Web: The Intersection of Energy Policy and Broader Governmental Policies” (2009) 5 (1) Texas Journal of Oil, Gas, \& Energy Law 1, 20.

121 F. Allen, Implementation of Oil Related Environmental Policies in Nigeria: Government Inertia and Conflict in the Niger Delta (Cambridge Scholars Publishing, 2012) 4.

122 ibid 4. 
Nigeria's reputation and may open windows of opportunities towards collaboration in reducing the overdependence on oil and gas, thereby ensuring that the exhaustible level of petroleum in Nigeria is reserved while at the same time promoting clean environment. ${ }^{123}$ Furthermore, the need to encourage energy security and access in Nigeria is a fundamental issue. Renewable energy could offer more opportunities for generation of electricity supply. Nigeria's energy needs can further be improved through the development of renewable energy. Thus, investment in renewable energy could have a positive impact on Nigeria and would address the energy problems of Nigeria.

McHarg's statement is also instructive: "Law is clearly not a substitute for political commitment, but legal and political commitments are mutually reinforcing: the stronger the legal framework, the harder it is to dismantle." 124 Having a forward-looking approach, it is opined that Nigeria's democratic government is emerging and the people are becoming more aware of what is expected of the government. The political class may not be able to continue in the light of the development in Nigeria if the common good of the nation is not allowed to prevail. That operates as an incentive for the government to promote renewable energy. Likewise, realization of access to electricity is 'a plus' on the path of the government and such is in tune with winning the goodwill of the people of Nigeria.

123 See I. Øverland and H Kjærnet, Russian Renewable Energy: The Potential for International Cooperation (Ashgate Publishing Limited 2009) 17.

124 A. McHarg, "Regulating for Sustainable Electricity Market Outcomes in Britain: Asking the Law Question" (2013) 30 Environmental and Planning Law Journal 302, 302 . 